\title{
Knowledge, attitude and practices about menopause and menopausal symptoms among midlife school teachers
}

\author{
Shabana Sultan, Amita Sharma*, Nitin Kumar Jain
}

Department of Obstetrics and Gynecology, Gandhi Medical College, Bhopal, Madhya Pradesh, India

Received: 23 September 2017

Revised: 04 October 2017

Accepted: 28 October 2017

\author{
*Correspondence: \\ Dr. Amita Sharma, \\ E-mail:dramita99@gmail.com
}

Copyright: (c) the author(s), publisher and licensee Medip Academy. This is an open-access article distributed under the terms of the Creative Commons Attribution Non-Commercial License, which permits unrestricted non-commercial use, distribution, and reproduction in any medium, provided the original work is properly cited.

\begin{abstract}
Background: This study is aimed towards women's knowledge and attitudes towards menopause as menopause brings multifaceted impact including psychomotor, vasomotor and cardiovascular changes on women`s health.

Methods: The population of interest consisted of 150 qualified teachers of age group 40 to 60 years and above from different colleges and schools of Bhopal city. The data was collected using predesigned questionnaire with inform consent and responses were analysed using simple percentages.

Results: In this study, mean age of menopause is 48.4 years and $92 \%$ of women had knowledge about menopause out of them $84 \%$ of women consider it to be a natural process. Working capacity of $66 \%$ of the women was affected while sexual life is affected in $56 \%$ of the women. $88 \%$ of the women were aware of hormonal replacement therapy but only $4.6 \%$ of women were taking HRT due to concerns regarding side effects.

Conclusions: Most of the women in our study are aware of menopause and its symptoms but they are not following healthy life style modifications. Increased awareness is required to prepare women for menopause.
\end{abstract}

Keywords: Attitude, Knowledge, Menopause, Practices

\section{INTRODUCTION}

Menopause is an important physiological change in woman`s life. World Health Organization (WHO) has defined post-menopausal women as those women who have stopped menstrual bleeding one year ago or stopped having periods as a result of medical or surgical intervention (Hysterectomy/Oopherectomy) or both. With increasing life expectancy, women spend $1 / 3 \mathrm{rd}$ of life in this phase. ${ }^{1}$ It is estimated that by the end of 2015 there will be 130 million elderly women in India, necessitating substantial amount of care. ${ }^{2}$

Women during the menopause period experience certain physical and psychological changes and face various problems such as urogenital, psychological-social, cardiovascular and neurological problems, etc. ${ }^{3,4}$
These problems not only cause great distress and disability for the person but also impose a lot of pressure on the limited resources of the countries' health care system. $^{5}$

Middle-aged women's health has been underscored as their social status and the standard of living has improved along with growth of the population of women, which was relatively faster than that of men population. Women in the transition from midlife to elder status are more likely to undergo various and complex health problems, and to draw medical attention due to an increased risk of lowered quality of elderly life caused by inappropriate management. ${ }^{6}$

Menopause is an unspoken, unattended, reality of life, the cause of which is still undeciphered completely by man. 
Menopause is one such midlife stage which might be overcome easily or make a lady miserable depending on her luck. This phase of life is shrouded with lots of myths and taboos. ${ }^{7}$

Menopausal symptoms, though well tolerated by some women, may be particularly troublesome in others. Severe symptoms compromise overall quality of life for those experiencing them. There is under-reporting of symptoms among Indian women due to socio cultural factors. According to literature, at least $60 \%$ of ladies suffer from mild symptoms and $20 \%$ suffer severe symptoms and $20 \%$ from no symptoms. ${ }^{8}$ The most common and severe symptoms are memory loss, recurrent fatigue, exhaustion and dry skin in Korean women at menopause period. The menopausal women showed significantly higher physical symptoms than perimenopausal women. ${ }^{9}$

Appropriate understanding of women that certain physical, mental, social and psychological changes occur during menopause helps them with greater readiness to cope with these changes. ${ }^{10}$

Overall subjective experience of menopause was perceived as increasingly positive with age. Awareness of menopausal symptoms appeared lower than expected. Peri-menopausal and menopausal women rarely sought medical care. ${ }^{11}$

Objective of present study was to assess the knowledge and attitude of menopause and menopausal symptoms, to assess perceived effect of menopause on femininity and description of feeling about attaining menopause and to study the common health practices in them following menopause.

\section{METHODS}

The study was conducted after taking required permission from the school and college authorities. This was a crosssectional observational study. This study included 150 female teachers of age group 40 to 60 years and above from different colleges and schools of Bhopal city.

\section{Inclusion criteria}

Female teachers in age group 40-60 years and above.

\section{Exclusion criteria}

- Women with serious systemic or local disease.

- Women with unnatural menopause.

- Women on any drug therapy.

A Self designed structured questionnaire was prepared addressing demographic features, age of menopause, knowledge and prevalence of menopausal symptoms, perception towards menopause and knowledge and attitude towards HRT and its uses. The questionnaire was provided to teachers those want to participate in the study. Informed consent was taken from teachers. Those teachers who required therapy were offered treatment.

\section{Statistical analysis}

The data obtained was coded, checked and analysed statistically by simple percentages and proportions.

\section{RESULTS}

In present study 150 teachers participated. We found that $58 \%$ (87 out of 150) women have already attended menopause. Majority of women were in age group 46 to 50 years $(42 \%)$. Mean age of menopause is 48.4 years.

Table 1: Age wise distribution.

\begin{tabular}{|c|c|c|}
\hline Age group & Number & Percentage \\
\hline 41 to 45 years & 21 & 14 \\
\hline 46 to 50 years & 63 & 42 \\
\hline 51 to 55 years & 59 & 39 \\
\hline$>55$ years & 7 & 5 \\
\hline
\end{tabular}

Most women $(81 \%)$ included in the study were $46-55$ years old, $5 \%$ women were more than 55 years old and $14 \%$ were in $41-45$ years age group.

Table 2: Distribution according to marital status.

\begin{tabular}{|lll|}
\hline Marital status & Number & Percentage \\
\hline Married & 117 & 78 \\
\hline Unmarried & 9 & 6 \\
\hline Divorcee & 6 & 4 \\
\hline Widow & 18 & 12 \\
\hline
\end{tabular}

Out of 150 women included in study $117(78 \%)$ were married, $18(4 \%)$ were widow, $9(6 \%)$ were unmarried and $6(4 \%)$ were divorcee.

Table 3: Distribution according to educational status.

\begin{tabular}{|lll|}
\hline Education & Number & Percentage \\
\hline PhD & 102 & 68 \\
\hline B. Ed & 9 & 6 \\
\hline M. A. & 6 & 4 \\
\hline B. A. & 18 & 12 \\
\hline
\end{tabular}

All women included in the study had received higher education. Out of which $68 \%$ were Ph.D.

Table 4: Distribution according to parity.

\begin{tabular}{|lll|}
\hline Parity & Number & Percentage \\
\hline 1 & 21 & 14 \\
\hline 2 & 105 & 70 \\
\hline 3 & 18 & 12 \\
\hline 4 & 6 & 4 \\
\hline
\end{tabular}


Most (70\%) women were second para while $14 \%$ had only one child, $12 \%$ were third para and $4 \%$ had 4 children.

Table 5: Source of information.

\begin{tabular}{|lll|}
\hline Source & Number & Percentage \\
\hline Friends/Relatives & 93 & 62 \\
\hline Tv/Radio & 24 & 16 \\
\hline Doctor & 15 & 10 \\
\hline Magazine & 3 & 2 \\
\hline Others & 15 & 10 \\
\hline
\end{tabular}

$92 \%$ of the participants had knowledge about menopause. $84 \%$ of them considered it to be a natural process while rest believed it to be a disease.

Most of them (62\%) received information about menopause/HRT from Friends and relatives. Television and radio has important role to spread such valuable information. $16 \%$ women received information from this media. Only $10 \%$ women consult with doctor.

Table 6: Awareness of long term complications.

\begin{tabular}{|lll|}
\hline Complication & Number & Percentage \\
\hline Osteoporosis & 63 & 42 \\
\hline Cardiovascular disease & 51 & 34 \\
\hline Post menopausal bleeding & 42 & 28 \\
\hline Breast cancer & 18 & 12 \\
\hline
\end{tabular}

Women included in the study were aware of osteoporosis (42\%) which was also most common long term complication of menopause. Cardiovascular disease, Post-menopausal bleeding, and Breast cancer were other complications after menopause, with which women were aware of $34 \%, 28 \%, 12 \%$ respectively.

Table 7: Positive perception.

\begin{tabular}{|lll|}
\hline Perception & Number & Percentage \\
\hline Life is easier and calmer & 72 & 48 \\
\hline Freedom from rituals & 69 & 46 \\
\hline Freedom from pregnancy & 54 & 36 \\
\hline $\begin{array}{l}\text { Menopause is associated } \\
\text { with maturity and dignity }\end{array}$ & 78 & 52 \\
\hline
\end{tabular}

Table 8: Negative perception.

\begin{tabular}{|lll|}
\hline Perception & Number & Percentage \\
\hline Period of loneliness & 51 & 34 \\
\hline End of sexual life & 42 & 28 \\
\hline Loss of femininity & 60 & 40 \\
\hline Familial problems & 27 & 18 \\
\hline Depressed and irritable & 30 & 20 \\
\hline
\end{tabular}

There were mixed positive $(52 \%)$ and negative $(48 \%)$ perception regarding menopause.

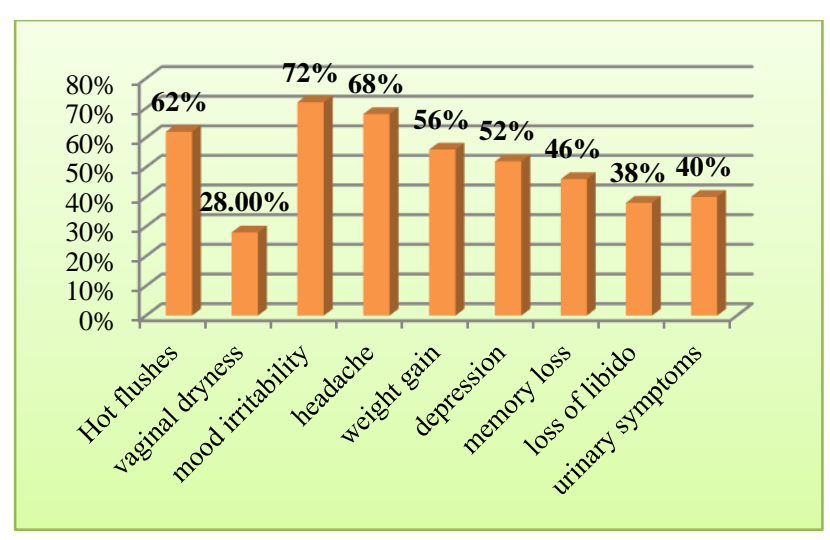

Figure 1: Menopausal symptoms.

$86 \%$ of subjects were aware about menopausal symptoms and maximum symptoms among subjects were mood irritability $(72 \%)$, headache $(68 \%)$ and hot flushes $(62 \%)$.

Table 9: Assessment of attitude towards HRT.

\begin{tabular}{|lll|}
\hline Attitude & Number & Percentage \\
\hline $\begin{array}{l}\text { HRT has side effects and } \\
\text { complications }\end{array}$ & 51 & 34 \\
\hline $\begin{array}{l}\text { HRT to be avoided } \\
\begin{array}{l}\text { Natural approaches are } \\
\text { better }\end{array}\end{array}$ & 42 & 28 \\
\hline $\begin{array}{l}\text { HRT is a good solution if } \\
\text { they had problems }\end{array}$ & 27 & 40 \\
\hline
\end{tabular}

$87.50 \%$ of the women were aware of hormonal replacement therapy and among them most of the subjects were concerned about the side effects and complication and complication of HRT. Hence only $4.6 \%$ of women were taking HRT.

Table 10: Effects of menopause.

\begin{tabular}{|lll|}
\hline Effect & Yes & No \\
\hline Working capacity & $66 \%(99)$ & $34 \%(51)$ \\
\hline Sexual life & $56 \%(84)$ & $44 \%(66)$ \\
\hline Knowledge about HRT & $88 \%(132)$ & $12 \%(18)$ \\
\hline
\end{tabular}

Working capacity was affected in $66 \%$ of women, and sexual life was affected in $56 \%$ of women.

$88 \%$ of women had knowledge about HRT (hormone replacement therapy).

Table 11: Attitude towards HRT.

\begin{tabular}{|lll|}
\hline Attitude & Number & Percentage \\
\hline $\begin{array}{l}\text { HRT has side effects and } \\
\text { complications }\end{array}$ & 117 & 78 \\
\hline HRT to be avoided & 18 & 12 \\
\hline Natural approaches are better & 27 & 18 \\
\hline $\begin{array}{l}\text { HRT is good solution if they } \\
\text { had problems }\end{array}$ & 21 & 14 \\
\hline
\end{tabular}


Table 12: Life style modification.

\begin{tabular}{|c|c|c|}
\hline Attitude & Yes & No \\
\hline Physical excercise & $32 \%$ & $68 \%$ \\
\hline Yoga/meditation & $11 \%$ & $89 \%$ \\
\hline Healthy eating plan & $41 \%$ & $59 \%$ \\
\hline Calcium supplementation & $18 \%$ & $82 \%$ \\
\hline
\end{tabular}

Nearly half (48\%) women preferred gynaecologist as treatment provider rest relied on physician (34\%) and general practitioner $(22 \%)$.

Eighty eight percent of the women were aware of hormonal replacement therapy and among them most of the subjects were concerned about the side effects and complication and complication of HRT. Hence only $4.6 \%$ of women were taking HRT. Maximum women have not adopted healthy practices.

About $40 \%$ of women never consult doctor and not using any method to relieve menopausal symptoms.

\section{DISCUSSION}

In this study $58 \%$ women were menopausal and $48 \%$ were peri-menopausal. Maximum subjects belonged to age group 46-50 years.

In present study we found mean age of menopause to be 48.4 years while in another study conducted in Gujrat in 2011 by Kishore et all it was 48.2 years and in study conducted in South Korea in 2006 by Eun Kyung Kwak et al it was 52.06 years. ${ }^{9}$

Ninety two percent women in this study had knowledge about HRT while in another study conducted in United Arab Emirates by Hamid S et al only $67 \%$ women had knowledge about menopause. ${ }^{12}$

$84 \%$ of the women considered it to be natural process while in another study conducted in Italy in 2008 by Serena Donati et al $95 \%$ of the women considered it to be a natural process. ${ }^{13}$

For maximum women (62\%) in this study received information regarding menopause from friends or relatives while in study conducted by Donati S only $59 \%$ women had it from friends/relatives and $72 \%$ from media and $69 \%$ from health professionals.

In this study $52 \%$ of the subjects were aware of long term consequences of menopause and amongst them $42 \%$ were aware that they will develop osteoporosis then cardiovascular diseases.

In present study women having mixed perception towards menopause. In present study working capacity of $65 \%$ of the women was affected and in $55 \%$ of the women sexual life was also affected. Maximum women have not adopted healthy practices.

\section{CONCLUSION}

Menopause and its symptoms, they are well educated but they are not following the healthy life style modification like healthy food habits, maintain healthy weight, being physically active, do weight bearing exercises, practice yoga/ meditation, calcium rich foods, sun exposure etc.

Knowledge of the concept of menopause will help women to understand that menopause is a normal developmental process. Increased awareness of hormonal variations and subsequent physical, physiological, psychological and sexual changes in the body will prepare women for menopause.

Reassurance and reliable information are prime requirements of women in pre-menopausal, perimenopausal and post menopausal period.

Husbands or men generally should be well informed about menopause, highlighting the stressful circumstances women go through, and the need for their husbands understanding and support. There should be mass media information dissemination to enlighten women on menopausal symptoms and effects.

Students in both secondary and tertiary institutions should be given lectures on menopause so as to prepare their minds from their youthful days.

Counselors in the medical setting are expected to teach their clients self-coping strategies, especially on the problems of menopause.

\section{ACKNOWLEDGMENTS}

Authors would like to thank college and school authorities and all those who have participated in this study and helped the authors in its implementation.

\section{Funding: No funding sources}

Conflict of interest: None declared

Ethical approval: The study was approved by the Institutional Ethics Committee

\section{REFERENCES}

1. Vaze N, Joshi S. Yoga and menopausal transition. J Midlife Health. 2010;1:56-8.

2. Mishra N, Mishra VN. Devanshi exercise beyond menopause: Dos and don'ts. J Midlife Health. 2011;2:51-6.

3. Abrernethy K. The menopause and HRT. 2th ed. Edinbiurg, London: Bailliere Tindall; 2002:65-7.

4. Khalil P, Motahhareh A, Mohammad A, Mohammad EM. Clinical guide and executive health programme team to provide menopausal services to women 60 75 years. Tehran: Pooneh Publication;2008:10-17.

5. Golyan Tehrani SH, Mir Mohammad Ali M, Mahmoudi M, Khaledian Z. Study of quality of life 
and its patterns in different stages of menopause for women in Tehran. J Fac Nurs Midwifery. 2002;8:3341.

6. Yeo JH. Sex-role attitude and management of menopause among middle-aged women in a local area. J Korean Soc Matern Child Health. 2004;8:199210

7. Kulshreshtha B, Ammini A. Hormone replacement therapy. In: Sharma OP, editor. Geriatric care: A textbook of geriatrics and gerontology. 3rd ed. New Delhi: Viva Books Publishers; 2008:647-50.

8. Tumbull S. Yoga as a treatment for menopausal symptoms. J Yoga Ontogenet Therap Investig. 2010;2:14-5.

9. Kwak EK, Park HS, Kang NM. Menopause knowledge, attitude, symptom and management among midlife employed women. J Menopausal Med. 2014 Dec; 20(3):118-125.

10. Noroozi E, Dolatabadi NK, Eslami AA, Hassanzadeh A, Davari S. Knowledge and attitude toward menopause phenomenon among women aged 40-45 years. J Educ Health Promot. 2013 May 30;2:25.
11. Yum SK, Yoon BK, Lee BI, Park HM, Kim T. Epidemiologic survey of menopausal and vasomotor symptoms in Korean women. J Korean Soc Menopause. 2012;18:147-154.

12. Hamid S. Women's knowledge, attitude and practice towards menopause and hormone replacement therapy: a facility based study in Al-Ain, United Arab Emirates. J Ayub Med Coll Abbottabad. 2014 Oct-Dec;26(4):448-54.

13. Donati S, Cotichini R, Mosconi P, Satolli R, Colombo C, Liberati A. Menopause: knowledge, attitude and practice among Italian women. Maturitas. 2009 Jul 20;63(3):246-52.

Cite this article as: Sultan S, Sharma A, Jain NK. Knowledge, attitude and practices about menopause and menopausal symptoms among midlife school teachers. Int J Reprod Contracept Obstet Gynecol 2017;6:5225-9. 